\title{
Human tonsil intraepithelial B cells: a marginal zone-related subpopulation
}

\author{
M Morente, M A Piris, J L Orradre, C Rivas, R Villuendas
}

\begin{abstract}
Aims: To determine if intraepithelial B cells in reactive human palatine tonsils were similar to the marginal zone cells of the spleen and Peyer's patches.

Methods: Reactive human palatine tonsils were studied using conventional methods of light microscopy, electron microscopy, and a panel of monoclonal antibodies for leucocyte common antigens.

Results: Clinically important numbers of marginal zone-related $B$ cells around the mantle zone were absent in lymphoid follicles, but in the cryptal epithelium there were abundant lymphoid cells with centrocyte-like nuclei and clear cytoplasm, intermingled with macrophages and plasma cells. The immunophenotype of these intraepithelial $B$ cells was distinctive and similar to that found in the splenic marginal zone cells (IgM +, IgD - , CD23 - , CD10 - , CD35 + , CD21 +, bc12+, KB61 +).

Conclusions: Intraepithelial $B$ cells in human tonsil could represent the counterpart of the marginal zone described in Peyer's patches. Their presence within the epithelium could reflect the destination for the malignant $B$ cells in the lymphoepithelial lesion of mucosa associated lymphoid tissue (MALT) lymphomas.
\end{abstract}

Human palatine tonsil lymphoid tissue has morphological, immunophenotypic, and pathological features similar to those of MALT.

Marginal zone B cells have been widely studied in splenic tissues. ${ }^{13}$ They are composed of perifollicular non-recirculating lymphocytes of clear medium sized cytoplasm and round or oval nuclei, which characteristically express IgM on their surface with little or no IgD. Cells of similar morphology and immunophenotype can also be found in lymph nodes ${ }^{34}$ and, mainly, in mucosa associated lymphoid tissue (MALT). ${ }^{56}$

In the lymph node these cells occur in the periphery of the follicular mantle zone, but this does not form a distinct zone, except for occasional reactive mesenteric lymph nodes. In several instances, such as toxoplasmic lymphadenitis and the lymphadenopathic period of HIV infections, marginal zone derived $\mathbf{B}$ cells form a distinct band at the periphery of the mantle zone and parasinusoidal spaces. In these cases the cells take on a monocytoid appearance and are designated "monocytoid B cells". ${ }^{78}$

In MALT marginal zone is represented by the so-called "mixed cell zone." These extrafollicular B cells are further distinguished by
Department of Pathology, Hospital General de

Guadalajara, Universidad de Alcalá de Henares, Spain

M Morente

Department of Pathology, Hospital Virgen de la Salud, Toledo, Spain

M A Piris

J L Orradre

$R$ Villuendas

Department of

Pathology, Fundación

Jimenez Diaz,

Universidad

Autonoma de Madrid, Spain

C Rivas

Correspondence to

Dr M Morente, Servicio de Anatomia Patologica,

Hospital General de Guadalajara, C/Donante de sangre s/n 19002

Guadalajara, Spain

Accepted for publication 2 October 199
Table 1 Polyclonal and monoclonal antibodies used

\begin{tabular}{|c|c|c|c|}
\hline$C D$ & Antibody & Specificiy & Source \\
\hline & Anti-Ig & B lymphocytes, monoclonal & Dako \\
\hline & Anti-Ig & B lymphocytes, polyclonal & Dako \\
\hline & GRB1 & HLA-DR & F Garrido (Granada, Spain) \\
\hline 19 & Leu12a & Pan-B & Becton-Dickinson \\
\hline 21 & OKB7 & B subsets & Ortho \\
\hline 22 & Leul4 & B subsets & Becton-Dickinson \\
\hline 23 & Tül & B subsets & Clonab \\
\hline \multirow[t]{2}{*}{38} & GR7A4 & Plasma cells, GC B cells & F Garrido (Granada, Spain) \\
\hline & Leu8 & Peripheral $\mathrm{T}$ and $\mathrm{B}$ cells & Becton Dickinson \\
\hline \multirow[t]{2}{*}{10} & CALLA & GC B cells & Ortho \\
\hline & $\mathrm{bcl} .2$ & B cells other than GC cells and small $T$ cells & DY Mason (Oxford) \\
\hline w32 & KB61 & B cell subsets, macrophages other than GC cells & DY Mason (Oxford) \\
\hline 35 & CRI & C $3 b R$, monocytes, B cells & Serotec \\
\hline 25 & IL2r & Activated $\mathrm{T}$ and $\mathrm{B}$ cells & T-cell sciences \\
\hline \multirow[t]{3}{*}{30} & BERH2 & Activated $\mathrm{T}$ and $\mathrm{B}$ cells. RS cells. & Dako \\
\hline & Ki67 & Proliferating cells & Dako \\
\hline & HML-1 & Intraepithelial $\mathrm{T}$ cells & Immunotech \\
\hline \multirow[t]{2}{*}{$11 \mathrm{c}$} & p150/95 & Monocytes & Dako \\
\hline & DRC & Follicular dendritic cells & Dako \\
\hline $1 \mathrm{a}$ & T6 & IDC, Langerhans' cells & Ortho \\
\hline 5 & $\mathrm{~T} 1$ & $\mathrm{~T}$ cells & Dako \\
\hline 2 & Leu5 & $\mathrm{T}$ cells & Becton Dickinson \\
\hline 3 & Leu4 & $\mathrm{T}$ cells & Becton Dickinson \\
\hline & TCR-delta & T cell subsets & T-cell sciences \\
\hline 45 & ALC & Leucocytes & Dako \\
\hline & $\mathrm{L} 26$ & B subsets & Dako \\
\hline \multirow{5}{*}{$\begin{array}{l}45 \mathrm{RO} \\
45 \mathrm{RA} \\
43 \\
68\end{array}$} & UCHL1 & $T$ subsets & Dako \\
\hline & Leu 18 & $B$ and $T$ subsets & Becton Dickinson \\
\hline & FT1 & $\mathrm{T}$ subsets & DY Mason (Oxford) \\
\hline & KP1 & Macrophages & DY Mason (Oxford) \\
\hline & PKK1 & Keratins & Labsystem \\
\hline
\end{tabular}

GC: Germinal centre. 

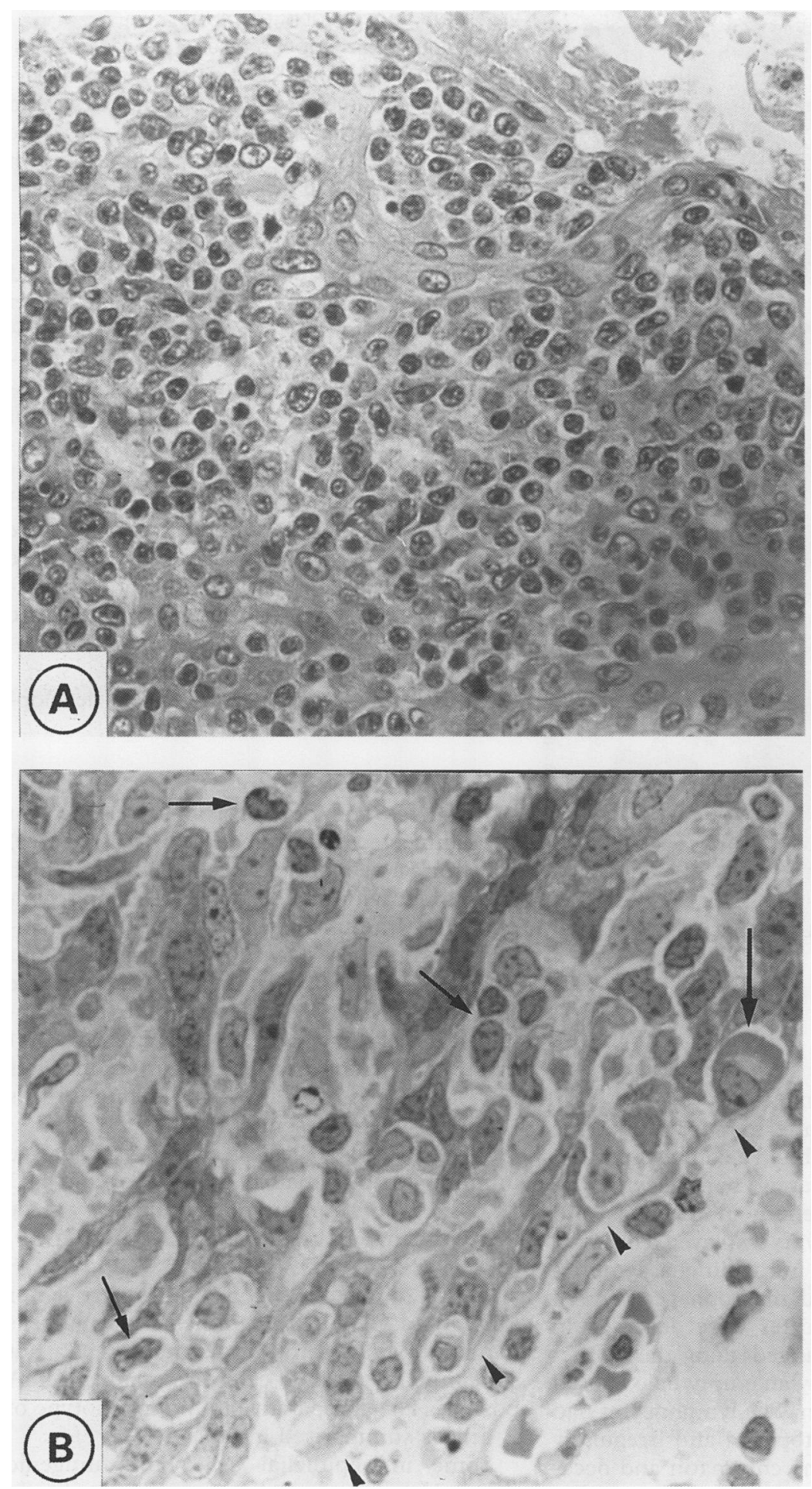

Figure 1 Intraepithelial lymphoid cells: (A) Nests of lymphocytes within the epithelium. (Giemsa) (B) Lymphocytes (short arrows) and plasma cells (long arrow) situated above basal membrane (Giemsa.) and hairy cell leukaemia has been raised by Burke and Sheibani. ${ }^{20}$

The function of splenic marginal zone cells and equivalent areas of other secondary lymphoid organs is still not fully known. A primary function attributed to marginal zone cells is their role in the primary response to thymus independent antigens type $2 .^{21}$

In the search for an analogy to the marginal zone we studied several reactive human palatine tonsils. The choice was based on the peculiarities of the organ: submucous situation, conspicuous development of lymphoid follicles without a distinct marginal zone, and notable presence of lymphoid cells within crypt epithelium. Because of the morphological similarities between tonsils and Peyer's patches, we started to compare the morphology and immunophenotype of the intraepithelial B cell subset of tonsils with both benign and malignant marginal zone from MALT and spleen.

\section{Methods}

Fresh, human palatine tonsils were obtained from routine surgical specimens, corresponding to 10 cases of recurrent tonsillitis. Immediately after tonsillectory one half of each specimen was processed for routine histopathological examination, fixed in B-5, embedded in paraffin wax, cut and stained with Giemsa and haematoxylin and eosin according to standard procedures. Part of each specimen was embedded on OCT compound (Milles Laboratory Inc, Naperville, Illinois, USA) and snap frozen in liquid nitrogen and stored at $-70^{\circ} \mathrm{C}$ until use.

Samples of tissue fixed in $2.5 \%$ glutaraldehyde, cacodylate buffer ( $\mathrm{pH} 7 \cdot 4$ ), postfixed in $2 \%$ osmium tetroxide, and embedded in Vestopal-W resin were studied ultrastructurally. Sections were stained with lead citrate and uranyl acetate and examined under a Hitachi HU-12A electron microscope.

Representative blocks of snap-frozen tissue from spleen, Peyer's patches, and lymph node, some of them from toxoplasmic lymphadenitis with abundant monocytoid B cells, were studied to characterise B cell compartments.

Paraffin wax sections and cryostat sections were stained with alkaline phosphatase antialkaline phosphatase (APAAP). ${ }^{22}$ Monoclonal antibodies were incubated at appropriate dilutions that had been determined in preliminary experiments. A humidity chamber at room temperature was used. The monoclonal and polyclonal antibodies used are listed in table 1 .

Briefly, $4 \mu \mathrm{m}$ sections were thawed to room temperature and fixed for 10 minutes in acetone and 30 minutes in chloroform. Primary monoclonal antibodies were incubated for 30 minutes. Sections were overlaid with antimouse immunoglobulins (Dako, Denmark) and APAAP complex (Dako, Denmark) for 30 minutes each step. The colour reaction was developed with alkaline phosphatase substrate and counterstained with haematoxylin. Brief TRIS-buffered saline washes were carried out between each step. gastrointestinal tract, ${ }^{69}$ thyroid, ${ }^{10}$ breast. ${ }^{15}$ Monocytoid B cell lymphomas have been reported in lymph nodes, ${ }^{16-19}$ but in some cases they could derive from MALT. The possible association between marginal zone 


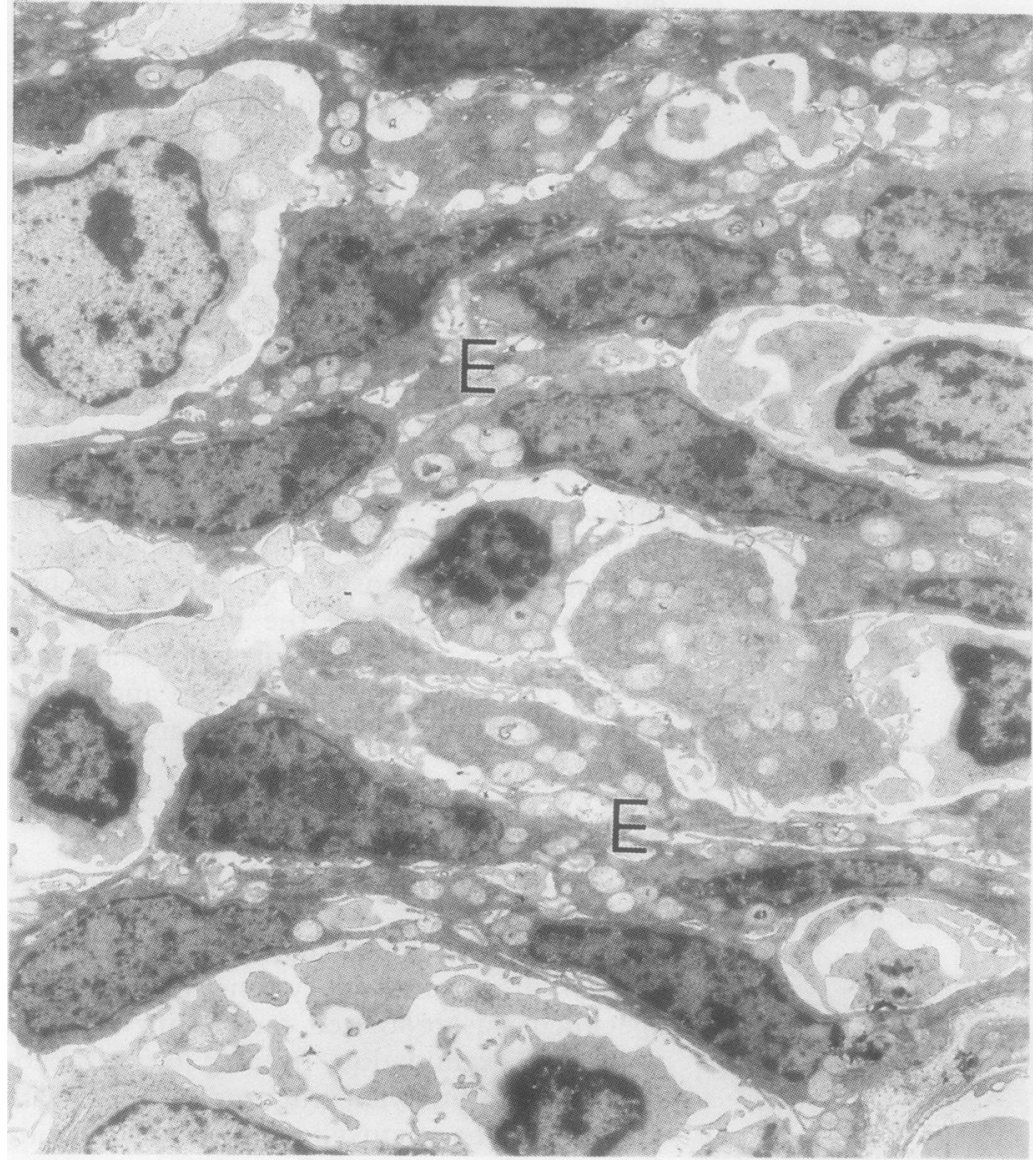

Figure 2 Electron micrograph showing criptal epithelium (E) with interspersed lymphocytes.
ELECTRON MICROSCOPIC FINDINGS

Epithelial cells appeared as large elements, containing electron dense mitochondria, peripherally situated to filament bundles, and some vacuoles (fig 2). Intraepithelial cells were recognised as lymphocytes, macrophages with tingible bodies, and granulocytes, mainly neutrophils. A spectrum of lymphoid cells was evident ultrastructurally (fig 3 ).

Centrocyte-like cells were medium sized lymphoid cells with oval and irregular nuclei with some indentations, marginal dense chromatin, and small single nucleoli. The cytoplasm contained few organelles, such as ribosomes, mitochondria and different degrees of development of rough endoplasmic reticulum.

There were some larger activated lymphoid cells with the same characteristics as those described above. The nuclei, however, were irregularly shaped and clearer because of diffuse chromatin distribution. Hyperplastic nucleoli and a well developed rough endoplasmic reticulum were also observed.

Plasma cells in different degrees of development were observed.

\section{IMMUNOHISTOLOGICAL FINDINGS}

In the neck and deep portions of the crypt interconnected epithelial cells (PKK1 positive) constitute a network of star-shaped cells which surround cavities filled with infiltrating lymphocytes. Immunostained intraepithelial lymphocytes in paraffin wax and frozen sections showed a similar pattern of reactivity in all the specimens studied. Surface epithelium contained $\mathrm{T}$ cells that were predominantly $\mathrm{CD} 4$ positive; in the crypt epithelium monocytes (1-5\%), T cells (10-20\%), and mainly B cells (80-90\%) were present (fig 4).

A percentage of $B$ cells seem to carry surface immunoglobulin, mainly $\operatorname{IgM}(70 \%)$ and IgD $(20 \%)$. The immunophenotype of these intraepithelial B cells was HLA-DR, CD19, CD21, CD22, CDw32, CD35, L26, Leu18 and bcl-2 positive (fig 5), but negative for CD10 and CD23. Intraepithelial plasma cells contain mainly intracytoplasmatic IgG, but subepithelial plasma cells are mainly CIgA positive. The comparative immunphenotype of B cells is summarised in table 2 .

Some intraepithelial cells have antigenic determinants recognisable by monoclonal antibodies directed against $\mathrm{T}$ cells $(\mathrm{CD} 2, \mathrm{CD} 3$,

Table 2 Reactivity of tonsilar intraepithelial B lymphocytes, compared with other B cell subpopulations

\begin{tabular}{|c|c|c|c|c|c|c|}
\hline $\begin{array}{l}\text { Monoclonal } \\
\text { antibody }\end{array}$ & $\begin{array}{l}\text { Marginal } \\
\text { zone }\end{array}$ & $\begin{array}{l}\text { Monocytoid } \\
\text { B lymphocytes }\end{array}$ & $\begin{array}{l}\text { Follicular } \\
\text { mantle zone }\end{array}$ & $\begin{array}{l}\text { Germinal } \\
\text { centre }\end{array}$ & $\begin{array}{l}\text { Plasma } \\
\text { cells }\end{array}$ & $\begin{array}{l}\text { Tonsilar } \\
\text { intraepthelial } \\
\text { B lymphocytes }\end{array}$ \\
\hline SIgM & + & + & + & + & - & + \\
\hline SIgD & - & - & + & - & - & $-1+$ \\
\hline CD19 & + & + & + & + & - & + \\
\hline CD21 & + & - & + & + & - & $+1-$ \\
\hline CD22 & + & + & + & $-1+$ & - & + \\
\hline $\mathrm{CD} 23$ & - & - & + & - & - & - \\
\hline CD38 & - & $-1+$ & - & + & + & $-1+$ \\
\hline BCL. 2 & + & $-1+$ & + & - & + & + \\
\hline LEU 18 & - & - & + & - & - & $+1-$ \\
\hline CD10 & - & - & - & + & - & - \\
\hline CD35 & + & - & + & $-1+$ & - & $+1-$ \\
\hline HLADR & + & + & + & + & - & + \\
\hline CDw32 & + & + & + & - & + & + \\
\hline
\end{tabular}



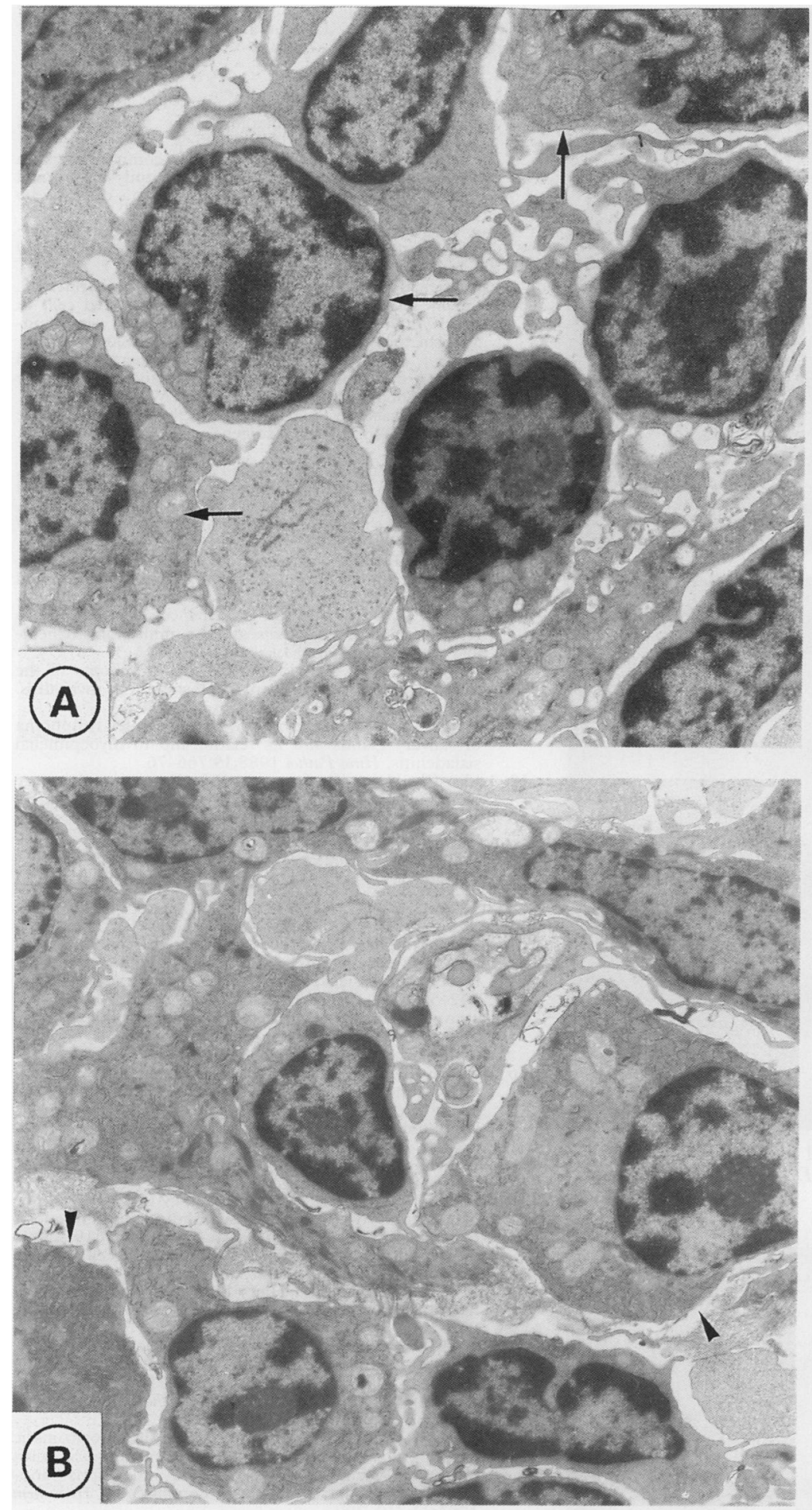

Figure 3 Electron micrograph showing intraepithelial centrocyte-like cells (A) (arrows) and plasma cells (B) (arrowheads). sue (MALT) may be an essential component in some organs-for example, in the mucosa of bronchi and, mainly, intestine-or acquired as a result of an autoimmune disorder as in the stomach, thyroid, or salivary glands. ${ }^{23}$

Morphologically, the most distinctive feature of MALT is the presence of a perifollicular rim of B cells with local epithelial tropism and noticeable immunophenotypic similarities with the B cells of the splenic marginal zone. These extrafollicular B cells are further distinguished by their size and nuclear morphology. They are larger than mantle zone cells and contain an irregular nuclear outline resembling that of centrocytes. ${ }^{23}$ Their similar lineage to monocytoid B cells has been pointed out by several authors, ${ }^{171924}$ mainly in connection with "marginal-zone related B cell lymphomas.",25

The organisation of human tonsil lymphoid tissue is distinctive and differs from that of peripheral lymph nodes, resembling those of MALT structures in the following ways: (1) absence of sinuses; (2) presence of intraepithelial macrophages presumably involved in antigen transport, like the mucosal cells of the intestinal epithelium; (3) intraepithelial lymphoid infiltrate, mainly B cells, contiguous with the marginal zone.

Characterisation of the intraepithelial B cells within the crypts of the human tonsils, shows a well defined morphological and immunophenotypical association with marginal zone. Thus follicle centre B cells (which are bcl.2-, $\mathrm{CD} 10+, \mathrm{KB} 61_{-}^{-}$) and follicle mantle $\mathrm{B}$ cells (which are $\mathrm{IgD}+, \mathrm{CD} 23+$ ) differ from the tonsilar intraepithelial B lymphocytes.

Partial loss of CD21 and CD35 antigens in some intraepithelial B cells may indicate the presence of activated cells with or without monocytoid morphology.

Tonsillar intraepithelial B lymphocyte localisation is reminiscent of the $B$ cells in the dome epithelium overlying follicle centres of Peyer's patches, ${ }^{5}$ intestinal epithelium in cases of florid reactive lymphoid hyperplasia of the terminal ileum, ${ }^{26}$ and of epithermotropism of the B cells in low grade B-MALT lymphomas. ${ }^{23}{ }^{24}$ Furthermore, lymphomas of Waldeyer's ring seem to share some characteristics of MALT lymphomas and tend to invade the epithelium. ${ }^{27}$ The classic lymphoepithelial lesions were not seen, however, perhaps reflecting the lack of glands in the tonsil. An association between the lymphoid tissue of Waldeyer's ring and gastrointestinal MALT is also strengthened by the increased risk of secondary disease in the tonsil in patients with gastrointestinal lymphoma, ${ }^{28}$ and the frequent relapses of Waldeyer's ring lymphomas in the gastrointestinal tract $^{29}$ or salivary glands. ${ }^{27}$ The epithelial tropism of this subpopulation may help to explain the epithelial infiltration of the tumours derived from the marginal zone cells in MALT, such as the low grade B cell lymphoma in the stomach, salivary gland, and thyroid.

We are grateful to D Y Mason (Oxford) and F Garrido (Granada, Spain) for the generous supply of antibodies. We thank A Bernal and P Embid (Guadalajara, Spain), I Galvez and A Muñoz (Toledo, Spain), and M Lagunar (Madrid, Spain) for technical assistance.

\section{Discussion}

A relatively independent mucosal immune system exists together with a systemic immune system. This mucosa-associated lymphoid tis- 

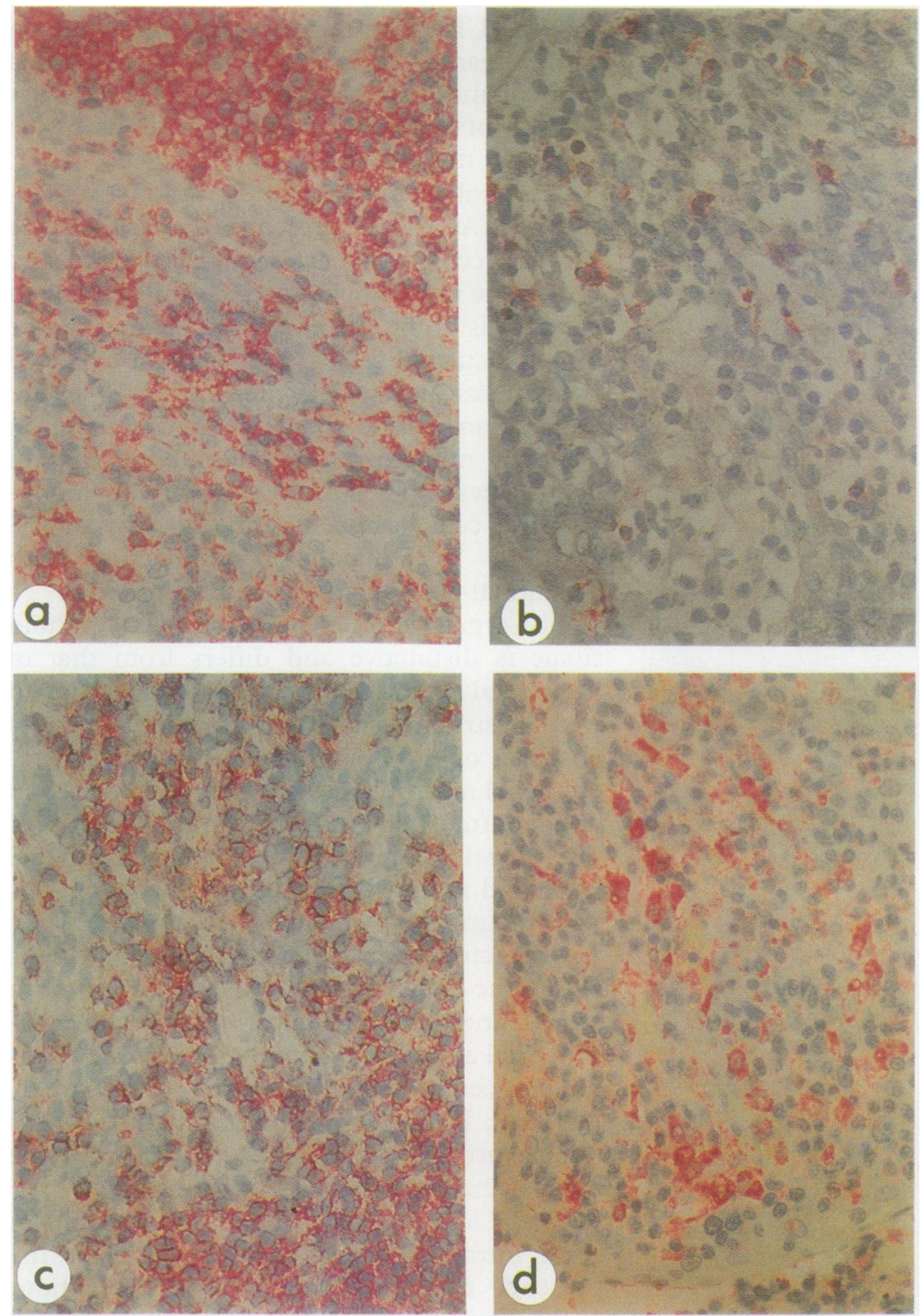

Figure 4 Intraepithelial lymphoid cells are mainly $B$ cells ( $A$ and $C$ ), with scattered $T$ cells (B) and macrophages (D) (A L26; B CD3; C CD19; D CD68).
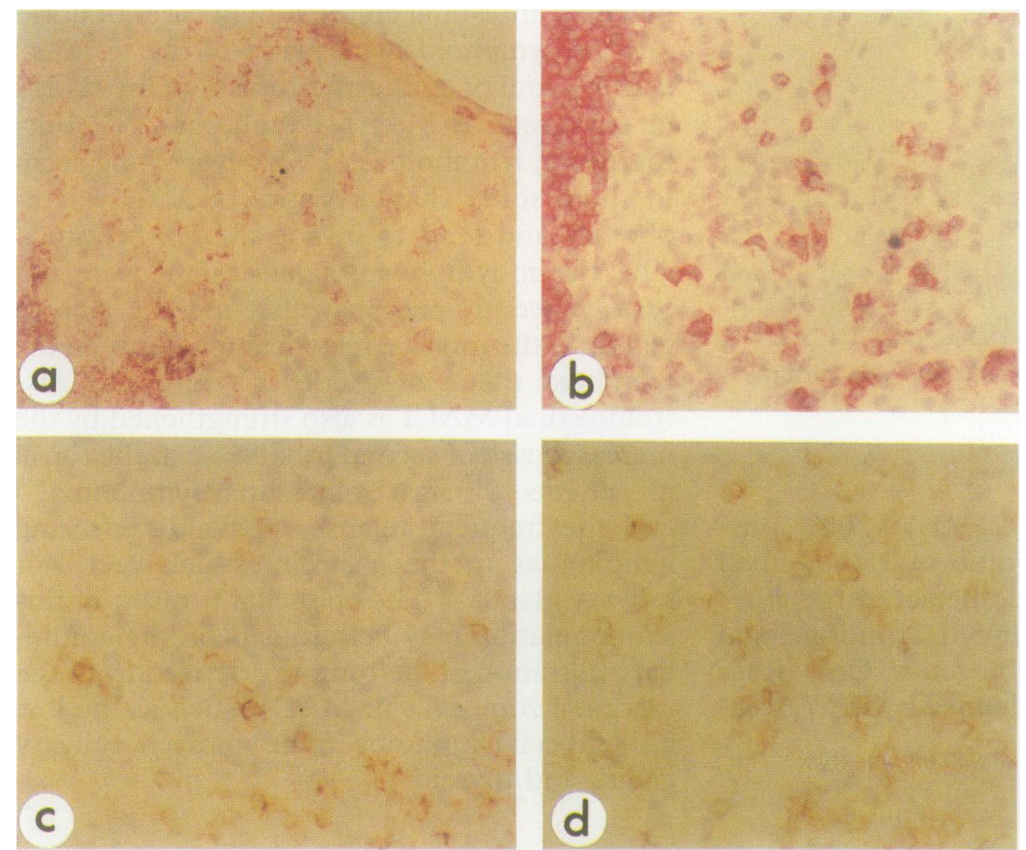

Figure 5 Intraepithelial $B$ cells express $C D 35(A)$ and $C D 21$ (B). They are mainly IgM+ (D) but only scattered IgD + cells are present (C). (A) CRI; B OKB7, C anti-IgD $D$ anti-IgM).
This study was supported by grants from the Fondo de Investigacion sanitaria (FIS) and Ministerio de Educacion y Ciencia (DGICYT)

1 MacLennan ICM, Gray D, Kumaratne DS, Bazin $H$. The lymphocytes of splenic marginal zone: a distinct B-cell lineage. Immunol Today 1982;3:305-7.

2 Timens W, Poppema S. Lymphocyte compartments in human spleen. A immunohistologic study in normal spleen and noninvolved spleen in Hodgkin's disease. $\mathrm{Am}$ f Pathol 1985;120:443-54.

3 Van der Oord JJ, De Wolf-Peeters C, Desmet VJ. The marginal zone in the human reactive lymph node. $A m \mathcal{F}$ Clin Pathol 1986;86:475-9.

4 Van Krieken JHJM, Von Schilling C, Kluin PM, Lennert K. Splenic marginal zone lymphocytes and related cells in the lymph node: a morphologic and immunohistochemical study. Hum Pathol 1989;20:320-5.

5 Spencer J, Finn T, Isaacson PG. Gut associated lymphoid tissue: a morphological and immunocytochemical study of the human appendix. Gut 1985;26:672-9.

6 Myhre MJ, Isaacson PG. Primary B-cell gastric lymphoma: a reassessment of its histogenesis. F Pathol 1987;152: a rease.

7 Van Den Oord JJ, De Wolf-Peeters C, De Vos R, Desmet VJ. Immature sinus histiocytosis. Light- and electron-microscopic features, immunologic phenotype, and relationship with marginal zone lymphocytes. $A m \mathcal{F}$ Pathol 1985;ii: $266-77$.

8 Piris MA, Rivas C, Morente M, Oliva $H$, Rubio C. Immature sinus histiocytosis. A monocytoid B-lymphoid reaction. F Pathol 1986;148:159-67.

9 Isaacson PG, Dogan A, Price SK, Spencer J. Immunoproliferative small-intestinal disease. An immunohistochemical study. Am f Surg pathol 1989;13:1023-33.

10 Hyjek E, Isaacson PG. Primary B cell lymphoma of the thyroid and its relationship to Hashimoto's thyroiditis. Hum Pathol 1988;19:1315-26.

11 Hyjek E, Smith WJ, Isaacson PG. Primary B-cell lymphoma of salivary glands and its relationship to myoepithelial sialadenitis. Hum Pathol 1988;19:766-76.

12 Addis BJ, Hyjek E, Isaacson PG. Primary pulmonary lymphoma: a re-appraisal of its histogenesis and its relationship to pseudolymphoma and lymphoid interstitial pneumonia. Histopathology 1988;13:1-17.

$13 \mathrm{Li} \mathrm{G}$, Hansmann ML, Zwingers T, Lennert K. Primary lymphomas of the lung: morphological, immunohistochemical and clinical features. Histopathology 1990;16: 519-31.

14 Issacson PG, Chan JKC, Tang C, Addis BJ. Low-grade B-cell lymphoma of mucosa-associated lymphoid tissue arising in the thymus. A thymic lymphoma mimicking myoepithelial sialadenitis. Am F Surg Pathol 1990;14: myoepitheli.

15 Lamovec J, Jancar J. Primary malignant lymphoma of the breast. Lymphoma of the mucosa-associated lymphoid tissue. Cancer 1987;60:3033-41.

16 Sheibani K, Burke JS, Swartz WG, Nademanee A, Winberg CD. Monocytoid B-cell Lymphoma. Clinicopathologic CD. Monocytoid B-cell Lymphoma. Clinicopathologic
study of 21 cases of a unique type of low-grade study of 21 cases of a unique

17 Piris MA, Rivas C, Morente M, Cruz MA, Rubio C, Oliva H. Monocytoid B-cell lymphoma, a tumour related to the marginal zone. Histopathology 1988;12:383-92.

18 Cogliatti SB, Lennert K, Hansmann ML, Zwingers TL. Monocytoid B-cell lymphoma: Clinical and prognosis features of 21 patients. $\mathcal{f}$ Clin Pathol 1990;43:619-25.

19 Piris MA, Orradre JL, Rivas C. Monocytoid B-cell lymphoma: a MALT tumour? Histopathology 1990;16:287-8.

20 Burke JS, Sheibani K. Hairy cells and monocytoid B lymphocytes: Are they related? Leukaemia 1987;1: 298-300.

21 Oldfield S, Yong-Jun L, Beaman M, MacLennan CM. Memory B-cells generated in T cell-dependent antibody responses colonise the splenic marginal zone. In: Fossum S, Rolstad B, eds. Histophysiology of the immune system. New York: Plenun Press, 1988:93-8.

22 Cordell JL, Falini B, Erber WN, et al. Immunoenzimatic labelling of monoclonal antibodies using immune complexes of alkaline phosphatase and monoclonal antialkaline phosphatase (APAAP complex). $\mathcal{f}$ Histochem 1984;32:219-29.

23 Isaacson PG, Spencer J. Malignant lymphoma of mucosaassociated lymphoid tissue. In: Habeshaw JA, Lauder I, eds. Malignant lymphomas. Edinburgh: Churchill Livingeds. Malignant lymphomas

24 Piris MA, Rivas C, Morente M, et al. Linfoma B gastrico de bajo grado originado en tejido linfoide asociado a
mucosas. Relación de las células tumorales con la zona marginal y los linfocitos B monocitoides. Estudio immunohistoquimico y ultraestructrual. Med Clin 1990;94: 601-6.

25 Isaacson PG, Spencer J. Monocytoid B-cell lymphomas. $\mathrm{Am}$ f Surg Pathol 1990;14:888-90.

26 Rubin A, Isaacson PG. Florid reactive hyperplasia of the terminal ileum in adults: a condition bearing a close terminal ileum in adults: a condition bearing a close resemblance to low-grade

27 Chan JKC, Ng CS, Lo STH. Immunohistological characterization of malignant lymphomas of the Waldeyer's ring
other than the nasopharynx. Histopathology 1987;11: other than

28 Ree HJ, Rege VB, Knisley RE, et al. Malignant lymphoma of Waldeyer's ring following gastrointestinal lymphoma. Cancer 1980;46:1528-35.

29 Saul SH, Kapadia SB. Primary lymphoma of Waldeyer's ring. Clinicopathologic study of 68 cases. Cancer 1985 ; 56:157-66. 